\title{
Benign carotenaemia in children
}

\author{
P J CONGDON, J KELLEHER, P EDWARDS, AND J M LITTLEWOOD \\ Department of Paediatrics and Department of Medicine, St James's University Hospital, Leeds
}

SUMMARY Six children presented with yellow pigmentation of the skin as a result of carotenaemia, and 5 were aged less than 1 year when this was first noted. Serum carotene levels depend on carotene intake, and absorption is promoted if food is of a fine texture. Five of the children were fed a partly homogenised diet. Pigmentation resolved when the carotene intake was reduced. This condition should be suspected, especially in young children, if the skin is yellow while the sclera remains a normal colour.

Yellow pigmentation of the skin is generally due to jaundice and is then accompanied by characteristic changes in the blood, urine, faeces, and mucous membranes. Carotenaemia - the result of a high serum carotene level-also leads to yellow pigmentation of the skin, but is not associated with colour changes in either the sclera or urine, an important clue in clinically excluding hyperbilirubinaemia. ${ }^{1}$ While there have been a few reports of benign carotenaemia in healthy children, ${ }^{2-5}$ high carotene levels can also be present in conditions associated with high serum lipids-namely hypothyroidism, diabetes mellitus, or nephrosis. ${ }^{4}$ As this change in skin colour causes parental concern, and as carotenaemia is not always considered and can be easily confirmed, we wish to report our findings in 6 children during the last 3 years.

\section{Methods}

Serum carotene $e^{6}$ and vitamin $\mathrm{A}^{7}$ concentrations were estimated on heparinised plasma samples. The plasma was separated as quickly as possible, generally within 2 hours and stored at $-20^{\circ} \mathrm{C}$ until analysed. All assays were carried out within 7 days of collection. As the patients were young, many of them attending outpatient clinics, it was not possible to obtain fasting samples.

\section{Case histories}

Case 1. This boy was seen at 7 months because of minor respiratory infections and his skin was noted to be faintly yellow, while the sclera remained a normal colour. The serum carotene concentration was found to be $510 \mu \mathrm{g} / 100 \mathrm{ml}(9.49 \mu \mathrm{mol} / \mathrm{l})$. His diet included strained foods containing carrots, and with a reduction in intake the level fell 6 weeks later to $300 \mu \mathrm{g} / 100 \mathrm{ml}(5.58 \mu \mathrm{mol} / \mathrm{l})$. Twelve and 24 months later the levels were $170 \mu \mathrm{g} / 100 \mathrm{ml}$ and $128 \mu \mathrm{g} / 100 \mathrm{ml}(3.16$ and $2.38 \mu \mathrm{mol} / \mathrm{l})$. Yellow pigmentation of his skin resolved. Thyroid and liver function tests were normal, as were his serum lipids.

Case 2. This girl had been born 4 weeks prematurely. She developed necrotising enterocolitis in the neonatal period which resolved with conservative management. On routine follow-up at 6 months her skin was yellow, while the sclera remained a normal colour. The serum carotene level was found to be $468 \mu \mathrm{g} / 100 \mathrm{ml}(8.7 \mu \mathrm{mol} / \mathrm{l})$. Her diet included about 3 jars of savoury foods a day in addition to other vegetables and fruit. With a reduction in the intake of carotene-containing foods, this pigmentation resolved. Liver and thyroid function tests were normal, as were her serum lipids.

Case 3. This girl's skin was first noticed to be yellow at 7 months. When seen at 12 months her carotene level was $320 \mu \mathrm{g} / 100 \mathrm{ml}(5.95 \mu \mathrm{mol} / \mathrm{l})$, and vitamin $A$ $102.5 \mu \mathrm{g} / 100 \mathrm{ml}(3.58 \mu \mathrm{mol} / \mathrm{l})$. Her diet was rich in carotene-containing foods and included both squash (a vegetable) and sweet potatoes. After a reduction in this intake the level fell 6 weeks later to $268 \mu \mathrm{g} / 100 \mathrm{ml}$ $(4.98 \mu \mathrm{mol} / \mathrm{l})$ and the yellow pigmentation subsequently resolved. Liver function tests were normal.

Case 4. At 11 months, while in hospital undergoing investigations for a congenital heart lesion, this boy's skin was noticed to be yellow, and the carotene level was found to be $340 \mu \mathrm{g} / 100 \mathrm{ml}(6 \cdot 32 \mu \mathrm{mol} / \mathrm{l})$. Part of his diet consisted of strained baby foods containing a high proportion of carrots. By reducing 
this intake the carotene level fell to $165 \mu \mathrm{g} / 100 \mathrm{ml}$ (3.06 $\mu \mathrm{mol} / \mathrm{l})$ and his skin pigmentation resolved. His serum lipids and liver function tests were both normal.

Case 5. This infant had been followed up regularly because he had been preterm (birthweight $1600 \mathrm{~g}$ ) and at 11 months his skin was found to be yellow, although the sclera were of a normal colour. The results of his serum lipids, liver, and thyroid function tests were normal. On two subsequent visits within the next 9 months this skin discoloration was still present. His serum carotene was not estimated until he was 2 years of age and it was then $147 \mu \mathrm{g} / 100 \mathrm{ml}$ $(2.73 \mu \mathrm{mol} / \mathrm{l})$, with a vitamin A level of $115 \mu \mathrm{g} / 100 \mathrm{ml}$ $(4 \cdot 0 \mu \mathrm{mol} / \mathrm{l})$. His diet contained carotene-rich foods and by reducing this intake the yellow pigmentation of his skin, which fluctuated in intensity, resolved. The serum carotene level fell to $37.5 \mu \mathrm{g} / 100 \mathrm{ml}$ $(0 \cdot 70 \mu \mathrm{mol} / \mathrm{l})$.

Case 6. This 5-year-old girl had been noted to be intermittently yellow for nearly a year. Thyroid and liver function tests were normal, as were her serum lipids. Her carotene intake was considered to be periodically excessive. By reducing her intake the yellow pigmentation resolved and the carotene levels fell from $176 \mu \mathrm{g} / 100 \mathrm{ml}(3 \cdot 28 \mu \mathrm{mol} / \mathrm{l})$ to $134 \mu \mathrm{g} / 100$ $\mathrm{ml}(2.49 \mu \mathrm{mol} / \mathrm{l})$. Her vitamin A level at the time of diagnosis was $95 \mu \mathrm{g} / 100 \mathrm{ml}(3 \cdot 3 \mu \mathrm{mol} / \mathrm{l})$.

\section{Discussion}

There are about 100 naturally occurring carotenoids chemically similar to $\beta$-carotene which are responsible for the yellowish-red colour of vegetables. Their general formula is $\mathrm{C}_{40} \mathrm{H}_{56} \mathrm{O}_{n}$ (where $\mathrm{n}$ is 0-6), the hydrocarbons (here $n=0$ ) are called carotenes, and the hydroxyl derivatives are xanthophylls. ${ }^{1}$ $\beta$-carotene, the most important, is found in carrots, green vegetables, and dairy products. It is absorbed in the small-intestine and converted by a mucosal enzyme, $\beta$-carotene 15,15 -deoxygenase to vitamin $A$ (retinol) which is then transported via lymphatics to the blood stream and liver. ${ }^{8}$

A comprehensive study by Clausen and McCoord $^{9}$ showed that after transplacental transfer, serum carotene levels continued to rise in the first 18 months, and subsequently fell to fairly constant levels by 5 years. The original isolated reports of carotenaemia were found in people who eat large quantities of foods rich in carotene, ${ }^{2-4}$ but high levels can occur in other conditions. In untreated diabetes mellitus and hypothyroidism-both associated with hyperlipidaemia-conversion of $\beta$-carotene to vitamin $A$ in the intestinal mucosa is impaired and may result in hypercarotenaemia. ${ }^{1}$
Because carotene is deposited mainly in the superficial horny layer of the skin, and as it is present in sweat and sebaceous material, pigmentation is particularly noticeable in areas where sweating is marked-namely the nasolabial folds, the palms, and the soles. ${ }^{4}$

The Interdepartmental Committee on Nutrition for National Defence suggested guidelines for carotene levels of less than $40 \mu \mathrm{g} / 100 \mathrm{ml}(0 \cdot 74$ $\mu \mathrm{mol} / \mathrm{l})$ as being low, $40-99 \mu \mathrm{g} / 100 \mathrm{ml}(0 \cdot 74-1 \cdot 84$ $\mu \mathrm{mol} / \mathrm{l})$ as acceptable, and levels greater than $100 \mu \mathrm{g} / 100 \mathrm{ml}(1.86 \mu \mathrm{mol} / \mathrm{l})$ as high. ${ }^{10}$ In our laboratory, levels in a group of healthy control children were $105 \pm 27 \mu \mathrm{g} / 100 \mathrm{ml}$ (mean \pm SD). Four of the 6 children had unequivocally high levels at the time of presentation (Cases 1-4), and the other 2 had levels about 2 SD above the mean value for our controls. All were noticeably yellow when these estimations were performed. In Case 5 there was a delay of 1 year before the condition was recognised: it is likely that his carotene level was higher when the skin pigmentation was more marked.

Although early reports stressed a seasonal variation in serum levels, ${ }^{9}$ this was probably due to the seasonal availability of vegetables at that time. Because carrots are cheap and readily available throughout the year, they are now added to most commercial varieties of strained savoury baby foods (H J Heinz Company Limited, 1980, personal communication). The content varies with particular foods, but those containing carrots may contain $>6000 \mu \mathrm{g}$ per jar and even those not containing carrots still have an appreciable $\beta$-carotene content added as vegetable colour. (The range in carotene content in one manufacturer's strained foods was 600-6000 $\mu \mathrm{g}$ per jar.*)

Yellow pigmentation of the skin was first noticed in 5 of our 6 children when they were less than 1 year. At this age they were consuming a diet containing strained foods, especially commercial varieties which contained carrots. Case 2 was also fed squash (a vegetable with a carotene content of $2000 \mu \mathrm{g} / 100 \mathrm{~g}$ ) and sweet potatoes (carotene content 4000-12 000 $\mu \mathrm{g} / 100 \mathrm{~g}){ }^{11}$ Unfortunately, we do not have accurate estimations of carotene intake, which because of considerable day-to-day variations are difficult to obtain. It was however, clear that all of these children consumed a diet rich in carotene-containing foods.

Yellow pigmentation of the skin was first noted in 5 of the 6 children when they were being fed an homogenised diet rich in carotene. It is known that food particle size is of considerable importance in the absorption of carotene. ${ }^{12}$ Children fed diets of small particulate size-that is homogenised or pureed *Data kindly supplied by $\mathbf{H} \mathrm{J}$ Heinz Company Limited. 
foods-have higher carotene levels than those fed similar but chopped diets. ${ }^{12}$ The change in the consistency of the diet with age partly explains why carotene levels fall after 18 months and why skin pigmentation may resolve even if the intake is not reduced. ${ }^{5}$

Rare cases of carotenaemia in association with vitamin A deficiency as a result of a defect in the 15-15 deoxygenase enzyme have been reported, ${ }^{13}$ but benign carotenaemia resulting from a high intake should result in high vitamin A levels. Although vitamin A levels also depend on the amount of preformed vitamin ingested, 3 of our 6 children had levels of between 95 and $115 \mu \mathrm{g} / 100 \mathrm{ml} \mathrm{(3 \cdot 3-4 \cdot 0}$ $\mu \mathrm{mol} / \mathrm{l})$. The normal range for vitamin $A$ in our control children was $45-120 \mu \mathrm{g} / 100 \mathrm{ml}(1 \cdot 57-4 \cdot 19$ $\mu \mathrm{mol} / \mathrm{l})$. The finding of high vitamin A levels almost certainly excludes a block in conversion of $\beta$ carotene to retinol as the cause of carotenaemia in these cases. It has been suggested that benign carotenaemia may occur secondarily to slow maturation of this enzyme. Initially this should be associated with high carotene/vitamin A ratios, and where estimated 3 of our 6 children had ratios of $3 \cdot 12,1 \cdot 85$, and $1 \cdot 28$ (mean ratio for our control children was $1 \cdot 28$ ). While two of these 3 ratios were high, to confirm this possibility it would be necessary to estimate vitamin A levels after oral loading with carotene. It is of interest that Case 2 had extensive necrotising enterocolitis in the neonatal period which could conceivably have impaired this enzyme function.

None of these children suffered clinically from liver disease, hypothyroidism, or diabetes mellitus. All had normal liver function tests. Thyroid function tests and serum lipids were normal in the children when estimated.

Josephs ${ }^{4}$ in a review suggested that carotenaemia is not necessarily harmless, although many of his patients were adults who had been on high intakes for a considerable time. Weakness, weight loss, hepatomegaly, and hypotension occurred after many years of excessive intake. All our patients were asymptomatic, apart from the pigmentation.
Although Case 3 had hepatomegaly, this was due to heart failure secondary to a congenital lesion.

When seen in infants, benign carotenaemia is probably the result of the ready availability and ease of preparation of foods rich in carotene. When homogenised the fine texture of this type of diet enhances carotene absorption. Individual variation in absorption or in maturation of the deoxygenase enzyme may explain why more infants are not affected.

\section{References}

1 Cohen of Birkenhead. Observations on carotenaemia. Ann Intern Med 1958; 48: 219-27.

2 Hess A F, Myers V C. Carotinemia. A new clinical picture. JAMA 1919; 73: 1743-5.

3 Hashimoto $H$. Carotinoid pigmentation of the skin resulting from a vegetarian diet. JAMA 1922; 78: 1111-2.

4 Josephs H W. Hypervitaminosis A and carotenaemia. Am J Dis Child 1944; 67: 33-43.

5 O'Neil R R. Letter: Benign carotenemia of infancy. Pediatrics 1963; 31 : 692.

6 Varley H. Practical clinical biochemistry, fourth edition. London: Heinemann, 1967: 217.

7 Kahan J. A method for the fluormetric determination of vitamin A. Scand J Clin Lab Invest 1966; 18: 679-90.

8 Olson J A, Hyaishi O. The enzymatic cleavage of $\beta$ carotene into vitamin $\mathrm{A}$ by soluble enzymes of rat liver and intestine. Proc Natl Acad Sci USA 1965; 54: 1364-70.

9 Clausen S W, McCoord A B. The carotinoids and vitamin A of the blood. J Pediatr 1938; 13: 635-50.

10 United States Interdepartmental Committee in Nutrition for National Defence. Manual for nutrition surveys, second edition. Washington DC: US Government Printing Office, 1963.

11 Paul A A, Southgate D A T. McCance and Widdowson's The composition of foods, fourth edition. London: HMSO, 1978: 188.

12 Patel H, Dunn H G, Tischler B, McBurney A K. Carotenaemia in mentally retarded children. I. Incidence and etiology. Can Med Assoc J 1973; 108: 848-52.

13 McLaren D S, Zekian B. Failure of enzymic cleavage of $\beta$ carotene. Am J Dis Child 1971; 121 : 278-80.

Correspondence to Dr J M Littlewood, St James's University Hospital, Department of Paediatrics, Beckett Street, Leeds LS9 7TF.

Received 28 January 1980 